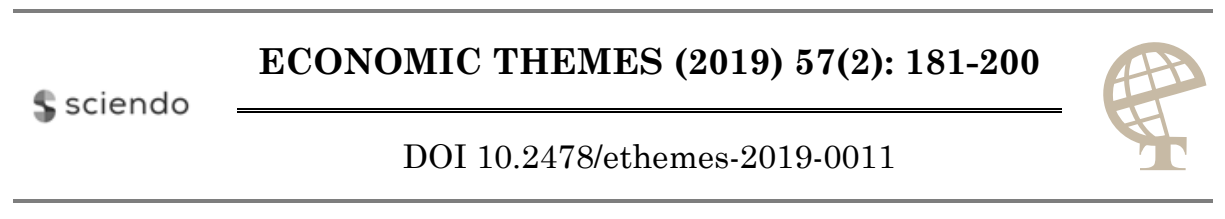

\title{
COMPARATIVE ANALYSIS OF EXECUTIVE COMPENSATION IN THE REPUBLIC OF SERBIA AND EU COUNTRIES
}

\author{
Ivana Marinović Matović
}

Addiko Bank AD Belgrade, Serbia

$\bowtie i v a n a m m @ s b b . r s$

\section{UDC \\ 005.337 \\ $(497.11+4-$ \\ $672 \mathrm{EU})$ \\ Review \\ paper}

Received:

02.02.2019

Accepted:

11.07.2019

\begin{abstract}
Executive compensations have a strong motivation role in contemporary business organizations. Adequate models of compensation enable attracting and retaining the high-capacity managers. This way, business organization conquers and maintains the competitive position in the context of globalization. It is necessary to align the executive compensation with the business organization's strategy, which requires careful process of planning, done by the highest levels of management and ownership. The main objective of the paper is to explore and compare the structure and the level of executive compensation in the Republic of Serbia and EU countries. The paper focuses on executive compensation components, primarily long-term and short-term incentives, as well as sallary and benefits. A comparative analysis of executive compensation models was performed to explain the differences in the observed countries.The study found large and disproportionate differences in the executive compensation levels, conditioned mostly by the economic development of the observed economies.
\end{abstract}

Keywords: Management, executive compensation, business organization, comparative analysis, the Republic of Serbia

JEL classification: M12, M52

\section{Introduction}

The highest management level has the role of creating a business organization strategy, as well as the task of defining organizational values. With appropriate reward of top management structures, their actions are directed towards achieving the defined business performances. Compensation models, which significantly influence the desired performance of managers, are of great interest in scientific and professional circles. The paper analyses executive compensation models, their structure and levels, in EU countries: United Kingdom, Germany, other EU 
countries and the Republic of Serbia.The comparative criterion with those countries of the European Union is the amount of overall executive compensation. According to the conducted research (Kotnik et al, 2017) managers in the UK and Germany make the highest compensations compared to other EU countries. The selected EU countries also have the highest ratio between executive compensations and compensation of other employees (Kotnik et al, 2017). The survey conducted in 2015 (Equilar, 2016) also confirmed that within the EU, the highest level of compensation is earned by managers in the United Kingdom and Germany.

The comparative analysis should provide answers to several research questions. First, it should confirm that there are large and disproportionate differences in executive compensation levels in observed countries. Secondly, it should determine the factors that directly or indirectly affect the executive compensation level. Thirdly, the research should confirm that some components of executive compensation, which exist in observed EU countries, have negligible participation in the Republic of Serbia.

\section{Importance of executive compensation in contemporary business organization}

Executive compensation strategy implies the development and application of rewarding policies, processes and practices over a longer period of time, in order to achieve business goals (Amstrong \& Murlis, 2004). It enables achievement of organizational business goals, and accordingly, needs to be developed and firmly linked to the planned business outcome. There is a strong link between organization's and compensation strategy, so any change of organization's strategy will also result in executive compensation change. Executive compensation strategy is aimed at achieving shareholder values and competitive advantage of business organization in the global market (Oppong, 2017; Beer \& Katz, 2003). It represents one of the most important motivation and control tool of the highest management structures.

Executive compensations studies developed nearly a hundred years ago, in the twenties of the 20th century, when first researches were conducted in the United States (Taussig \& Barker, 1925). Contemporary executive compensations studies are considered to have evolved in the eighties of the 20th century, with the emergence of agency theory or principal-agent theory (Jensen \&Meckling, 1976; Murphy, 1999). The agency theory analyses the relationship between managers as agents, and owners as principals, and is based on the view that owners make agency loss because they don't have direct control over the organization (Jensen \& Meckling, 1976). The agency theory advocates linking the interests of managers with the interests of owners, as two opposing parties, which is achieved by contracts defining executive compensations (Fama, 1980; Grossman \& Hart, 1983). 
According to agency theory, compensating the desired behaviour of managers leads to the achievement of business performances. However, executive compensation models do not lead in each case to the desired motivation of managers, since each individual is motivated differently (Srivastava, 2005).The expectancy theory or expectancy theory of motivation argues that the motivation of the individual stems from the expectation, and that it is important to achieve and maintain a stable relationship between motivation, performances, and compensation (Vroom, 1964). The foregoing implies the importance of creating different compensation models that will achieve the maximum motivation of a particular individual (Dobre, 2013). The agency theory and the expectancy theory represent significant attitudes that form the basis for the executive compensation, that is, define the conditions to be fulfilled by the effective executive compensation (Buble \& Bakotić, 2013).

Factors with the most significant influence on executive compensation are: business organization size, organization growth opportunity, risk, capital structure, ownership structure and the managers' age (Polak et al., 2014). The business organization size is of great importance for the executive compensation level, since those organizations demand the executives of the highest quality and significant business skills and experience(Frydman \& Jenter, 2010). Qualified and experienced executives at the highest management positions require significant and custom-made compensation models, due to the nature and responsibility of the work they perform (Frydman \& Jenter, 2010).

A business organization with growth opportunitywill put emphasis on executive compensation (Heskett, 2007). Compensation risk is immanent with contemporary business organizations, resulting in numerous financial instruments that owners use to protect against the misuse of compensation models (Trebilcock, 2011). The capital structure is important in determining salary, as the basic component of the executive compensation. The ownership structure of business organization also has an impact on executive compensation model. The state majority-owned organizations generally have different structure and level of executive compensations, in contrast to private equity-owned organizations (Cambini, et al., 2016). The managers' age also influences the level and structure of applied model of executive compensation. Older managers are focused on longterm goals, while younger managers place emphasis on short-term goals (Goodwin et al., 2010). Managers who have a long-term engagement within business organization, who have more knowledge and experience, will expect compensation model in accordance with their acquired experience and business skills (Heskett, 2007). The applied executive compensation model should be competitive in comparison with banchmark business organizations. The executive compensation model should also be attractive enough and tempting, which is achieved by an adequate combination of material and immaterial, fixed and variable components (Marinović-Matović, 2011). Fixed components of compensation provide security 
and high standard of living to managers. The variable components of compensation model motivate managers to achieve desired business performances. The structure of executive compensation model represents the choice of each business organization. A fixed components of the compensation model contain basic salary and benefits, while the variable components include short-term and long-term incentives.Longterm incentives, as an element of total executive compensation, have been designed with the aim of achieving long-term goals (Pepper et al., 2013). The time period, in which business performance is perceived, is usually 3 to 10 years. The incentive level depends on the achievement of business organization's goals. Manager can earn a significant reward, in case of achieving or exceeding the given business performances. Forms of long-term incentives are different; they are based on the involvement of managers in the ownership (Marinović Matović, 2011).

The executive compensation strategy focuses on managers' expectations in terms of salary, benefits and promotion opportunities, as well as achieving the desired goals of business organization in the global market.The strategy of executive compensation covers (Chingos, 2004):

- the definition of a competitive market

- the desired position of the various components of executive compensation

- the desired model of total compensation

- the desired relationship between the achieved business performances and the compensation

- the importance of capital, the value creation for the owners and the participation of the highest management levels in ownership

- the compliance with key legislative, tax and accounting regulations

- the executive compensation model in a business organization outside of the country's borders

The executive compensation in dislocated units of business organization most often are identical to those in their home country. In order to change the location of top managers, a unique reward strategy is necessary, as well as the structure of executive compensation (Galetić, 2012). Determining the level and structure of executive compensation is within the scope of the supervisory board, remuneration committee and compensation advisers. The supervisory board oversees the work of the board of directors, directs and controls the compensation policy, and decides on executive compensation models for the highest management levels. The remuneration committee provides support and assistance to the supervisory board in determining the executive compensation model, while the compensation advisor defines competitive and accountablecompensation models for the highest management structure (Galetić, 2012). 


\section{Executive compensation in the Republic of Serbia and EU countries}

Executive compensation models in EU countries are significantly shaped by global economic crisis, which manifested itself in 2008 (Marinović Matović, 2012). Global economic crisis has strongly influenced national economies and the world economy, and left a strong impact on EU countries, accompanied by employment restrictions and reduction in working hours. The recession has also led to astricter control of executive compensations, which implied new legislation (Kotnik et al., 2017). A few years after the global economic crisis outbreak, in 2012, EU business organizations conducted salary freezing, including primarily managers' salaries, and taxing higher levels of material rewards (Mercer, 2013). Deferred incentive payments have been introduced in most EU countries since the beginning of 2011, due to a new EU regulations regarding the capital level for credit and investment institutions, which covers $43 \%$ of business organizations (Kotnik et al., 2017). Since 2013, EU business organizations have accepted the awareness of compensation risks and included them in the process of managing other strategic and operational risks.

Regardless of the foregoing facts, executive compensations in the top 100 business organizations in European countries are still about seven times higher than in SME organizations, and 40 times higher than average salary in those countries (CIPD, 2017). Executive compensation in European countries consists of incentives and other variable components $(56 \%)$, while the remaining $44 \%$ are salaries and other fixed components (Haygroup, 2013). The global survey, conducted by Pedersen \& Partners in 2013, included a sample of 1,700 managers from 17 national economies and 330 business organizations in Europe (Pedersen \& Partners, 2013). This survey provided information about level and structure of executive compensation. Level of executive compensation, including short-term incentives, amounts to around 1.3-1.4 million EUR gross, annually (Pedersen \& Partners, 2013). During 2013, the average amount of executive compensation, in business organizations with over 100,000 employees, amounted to 1.35 million EUR gross per year. This amount includes 660,000 EUR of basic salary and 690,000 EUR of incentives, while the total amount of executive compensation was increased by $3.4 \%$ (Pedersen \& Partners, 2013). According to Pedersen \& Partners research, EU countries have the highest levels of executive compensation compared to other European countries, which is closely related to the size of business organizations (Pedersen \& Partners, 2013).Table 1 shows the average level of executive compensation in EU countries, with particular emphasis on United Kingdom and Germany as the most developed members, and compares it with the Republic of Serbia. The data relate to business organizations with more then 100 employees, and show the amount of annual gross compensationat (Pedersen \& Partners, 2013). 
Table 1. Average executive compensation (gross) in 2013

\begin{tabular}{|c|c||}
\hline Country & $\begin{array}{c}\text { Average executive compensation } \\
\text { (EUR) }\end{array}$ \\
\hline United Kingdom & 220.200 \\
\hline Germany & 215.000 \\
\hline Other EU countries & 131.323 \\
\hline The Republic of Serbia & 72.800 \\
\hline
\end{tabular}

Source: Pedersen \& Partners. (2013). Compensation in World's Largest Corporations Increased by $5.5 \%$. Retrieved from https://www.pedersenandpartners.com/news/2013/100920131441/compensation-world\%E2\%80\%99s-largest-corporations-increases-55

Another international research was conducted between 2014 and 2016; with the aim of determining the structure of executive compensation in European and several other countries. The research was organised by international network of business schools, Cranet (Cranet, 2017). It was carried out in 35 countries, summarised into three categories: countries that are currently EU members; six European countries that are not EU members; and the non-European countries (Australia, Brazil, China, Indonesia, Israel, The Philippines, South Africa, and the USA). Cranet survey was conducted in business organizations with at least 100 employees. Research has shown the increasing use of variable components of compensation, both financial participation (shares, profit sharing, stock options) and performance related pay (benefits, performance related pay, incentives). Variable components in the form of financial participation are used less than performance related pay, as confirmed by research. This diversity between countries is based on cultural differences, differences in business regimes and differences in legal regulations (Cranet, 2017). So share schemes are used in most countries, especially in Spain, Belgium and Slovakia. Profit sharing is mostly used in French Republic, the Netherlands, Germany, Austria and Belgium, i.e. those countries that have appropriate legal and tax regulations. Stock options are used a lot in Belgium and Spain (Cranet, 2017).

Table 2 shows application of different variable components of compensation in EU countries in period 2014-2016, with particular emphasis on the United Kingdom and Germany as the most developed members, and compares it with the Republic of Serbia.

As shown in Table 2, Germany has the widest use of financial participation within EU countries ( $15 \%$ shares, $55 \%$ profit sharing, and $11 \%$ stock options); while in the United Kingdom the use of share plans, profit sharing and stock options is balanced, as well as in other EU countries. Variable pay based on the performances is more used in EU countries then variable pay based on financial participation. The same applies to the Republic of Serbia, where only a small number of organizations use share plans $(6 \%)$ and stock options $(6 \%)$ (Cranet, 2017). 
Table 2: Application of variable components of compensation 2014-2016

\begin{tabular}{|c|c|c|c|c|c|c|c|c|c|}
\hline \multirow[b]{2}{*}{ Country } & \multicolumn{3}{|c|}{ Financial Participation } & \multicolumn{6}{|c|}{ Performance Related Pay } \\
\hline & 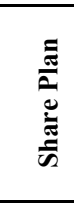 & 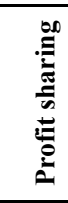 & 苛 & 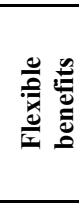 & 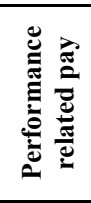 & 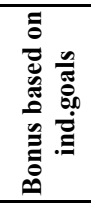 & 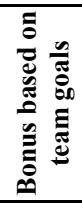 & 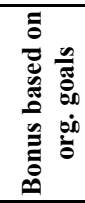 & 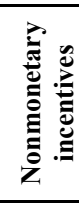 \\
\hline $\begin{array}{l}\text { Other EU } \\
\text { countries }\end{array}$ & $17 \%$ & $26 \%$ & $14 \%$ & $37 \%$ & $58 \%$ & $63 \%$ & $43 \%$ & $50 \%$ & $50 \%$ \\
\hline $\begin{array}{l}\text { United } \\
\text { Kingdom }\end{array}$ & $18 \%$ & $17 \%$ & $12 \%$ & $37 \%$ & $60 \%$ & $64 \%$ & $36 \%$ & $70 \%$ & $58 \%$ \\
\hline Germany & $11 \%$ & $55 \%$ & $15 \%$ & $55 \%$ & $69 \%$ & $74 \%$ & $41 \%$ & $58 \%$ & $52 \%$ \\
\hline $\begin{array}{l}\text { Republic } \\
\text { of Serbia }\end{array}$ & $6 \%$ & $19 \%$ & $6 \%$ & $23 \%$ & $72 \%$ & $60 \%$ & $45 \%$ & $55 \%$ & $46 \%$ \\
\hline
\end{tabular}

Source: Cranet. (2017). Cranet survey on comparative human resource management: International Executive Report. Retrieved from https:/www.fdv.uni-lj.si/docs/defaultsource/cpocv-doc/cranet-international-report-2017.pdf?sfvrsn=4.

\subsection{Executive compensation in the United Kingdom}

Average executive compensation in the United Kingdom is among highest, compared to other EU countries. This is one of the results of a global research performed by Pedersen \& Partners in 2013 (Pedersen \& Partners, 2013). Research was conducted in 17 countries, among 330 organizations and 1700 managers. Table 3 shows the average executive compensations in the United Kingdom in 2013. The structure of executive compensation includes basic salary, cash incentives, as well as stock options. The data are divided according to the business organization size, those with over 100,000 employees, and those with 20,000 to 50,000 employees (Table 3). As indicated by the data, highest levels of compensations were made by executives in organizations with over 100.000 employees; where incentives make $44 \%$ of total compensation (cash incentives and stock options). Managers in organizations with 20.000-50.000 employees have made significantly smaller compensations, and higher share of basic salary ( $77 \%$ of total compensation).

Table 3. Average executive compensation in the United Kingdom in 2013

\begin{tabular}{|c|c|c|c|c||}
\hline \hline $\begin{array}{c}\text { Number of } \\
\text { employees }\end{array}$ & $\begin{array}{c}\text { Basic } \\
\text { salary } \\
\text { (EUR) }\end{array}$ & $\begin{array}{c}\text { Cash } \\
\text { incentives } \\
\text { (EUR) }\end{array}$ & $\begin{array}{c}\text { Total material } \\
\text { compensation } \\
\text { (EUR) }\end{array}$ & $\begin{array}{c}\text { Incentives in } \\
\text { stock options } \\
\text { (EUR) }\end{array}$ \\
\hline Over 100.000 & 747.200 & 544.100 & 1.291 .300 & 31.200 \\
\hline 20.000 to 50.000 & 515.700 & 258.100 & 773.800 & $/$ \\
\hline
\end{tabular}

Source: Pedersen \& Partners. (2013). Compensation in World's Largest Corporations Increased by $5.5 \%$. Retrieved from https://www.pedersenandpartners.com/news/2013/10092013-

1441/compensation-world\%E2\%80\%99s-largest-corporations-increases-55. 
We can compare this information with the amount of compensation for other UK employees. The Hudson Annual Compensation Review for 2015 shows the range of com pensation on annual basis in certain UK cities (Hudson, 2015). The compensation includes the basic salary, pension contributions, incentives and stock options. According to data from Hudson, in small and medium-sized business organizations, the compensation amounts to a maximum of 31,000 GBP ie 39.680 EUR (Hudson, 2015).

\subsection{Executive compensation in Germany}

Average executive compensationin Germany, according to a global research performed by Pedersen \& Partners in 2013 (Pedersen \& Partners, 2013) is presented in Table 4. Levels of basic salary, cash incentives and total material compensation, as well as stock options, were shown. Data also included business organizations with over 100,000 employees and those employing between 20,000 and 50,000 employees. The following results were obtained:the basic salary of executives in Germany is lower than the basic salary in the UK, while the amount of cash incentives is higher in Germany than in the UK. The total executive compensation was higher in Germany than in the UK in observed period. The highest levels of compensations were made by executives in organizations with over 100.000 employees (1.441.100 EUR); where incentives make 58\% of total compensation (cash incentives and stock options). Managers in organizations with 20.000-50.000 employees have made significantly smaller compensations (814.000 EUR), and smaller share of incentives (39\% of total compensation).

Table 4. Average executive compensations in Germany in 2013

\begin{tabular}{||c|c|c|c|c||}
\hline \hline $\begin{array}{c}\text { Number of } \\
\text { employees }\end{array}$ & $\begin{array}{c}\text { Basic } \\
\text { salary } \\
\text { (EUR) }\end{array}$ & $\begin{array}{c}\text { Cash } \\
\text { incentives } \\
\text { (EUR) }\end{array}$ & $\begin{array}{c}\text { Total material } \\
\text { compensation } \\
\text { (EUR) }\end{array}$ & $\begin{array}{c}\text { Incentives in } \\
\text { stock options } \\
\text { (EUR) }\end{array}$ \\
\hline Over 100.000 & 701.100 & 740.000 & 1.441 .100 & 95.000 \\
\hline 20.000 to 50.000 & 495.000 & 319.000 & 814.000 & $/$ \\
\hline
\end{tabular}

Source: Pedersen \& Partners. (2013). Compensation in World's Largest Corporations Increased by $5.5 \%$. Retrieved from https://www.pedersenandpartners.com/news/2013/10092013-

1441/compensation-world $\%$ E2\%80\%99s-largest-corporations-increases-55.

Since 2007, short-term incentives were singled out as the most important component of executive compensation in Germany, which made up $47 \%$ of the total executive compensation (Koch \& Stadtmann, 2013). According to Koch \& Stadtmann (2013), a fixed component of executive compensation (basic salary) has a share of $33 \%$ in total compensation.

In 2009, Germany was heavily affected by the economic crisis, which led to a $5 \%$ reduction in GDP (Grund \& Walter, 2013). The repeated economic growth from 2011 resulted in an increase of incentive payments (and total executive compensations) to amounts higher than in precrisis period. 


\subsection{Executive compensation in other EU countries}

Average executive compensation in other EU countries, in organizations with more than 100.000 employees, were 1.294.000 EUR in 2013, with incentives reaching $56 \%$ of total compensation (Pedersen \& Partners, 2013). Executive compensations in organizations with 20.000-50.000 employees were significantly smaller (759.800 EUR), and incentives reached $28 \%$ of total compensation (Table 5).

Table 5. Average executive compensations in other EU countries in 2013

\begin{tabular}{|c|c|c|c|c||}
\hline $\begin{array}{c}\text { Number of } \\
\text { employees }\end{array}$ & $\begin{array}{c}\text { Basic } \\
\text { salary } \\
\text { (EUR) }\end{array}$ & $\begin{array}{c}\text { Cash } \\
\text { incentives } \\
\text { (EUR) }\end{array}$ & $\begin{array}{c}\text { Total material } \\
\text { compensation } \\
\text { (EUR) }\end{array}$ & $\begin{array}{c}\text { Incentives in } \\
\text { stock options } \\
\text { (EUR) }\end{array}$ \\
\hline Over 100.000 & 650.000 & 644.000 & 1.294 .000 & 82.200 \\
\hline 20.000 to 50.000 & 549.800 & 210.000 & 759.800 & $/$ \\
\hline
\end{tabular}

Source: Pedersen \& Partners. (2013). Compensation in World's Largest Corporations Increased by $5.5 \%$. Retrieved from https://www.pedersenandpartners.com/news/2013/100920131441/compensation-world\%E2\%80\%99s-largest-corporations-increases-55.

\subsection{Executive compensation in the Republic of Serbia}

Executive compensation research in Serbia was conducted by the Delegation of the German Economy in Serbia and the German-Serbian Economic Association, in cooperation with Kienbaum Management Consultants in 2012 (Vučković, 2012). The research involved 21 privately owned business organizations, both domestic and foreign capital, and 1,012 employees working in 25 positions. The research has covered organiztaions belonging to: mechanical sector (24\%), financial sector $(18 \%)$, electronic sector $(14 \%)$, chemical and pharmaceutical sector $(14 \%)$, metal sector $(10 \%)$, food sector with tobacco industry $(10 \%)$ and transport and logistics sector $(10 \%)$.

Executive compensation, according to this research, ranges from 2,500,000 to $13,500,000$ RSD (from 21,984 to $118,715 \mathrm{EUR}$, calculated according to the middle exchange rate of the euro by applying fixed exchange rates of the European Central Bank). The compensation of leading managers is from 450,000 to $8,500,000 \mathrm{RSD}$ (3,957 - 74,746 EUR), and ofdepartment managers from 250,000 to 3,600,000 RSD $(2,198-31,657$ EUR). Observed at the average level and by certain executive positions, the average amount of executive compensation (gross) is presented in Table 6.

The results of the research have shown that the variable components of executive compensation represent a very small percentage of total compensation. The participation of variable components in total executive compensation is only 5\% (Vučković, 2012). Observed by position, research has shown that key account managers receive the highest percentage of variable components $(25 \%)$, followed by general managers (8\%), and other leading managers (7\%) (Vučković, 2012). 
Table 6: Average executive compensations in the Republic of Serbia in 2012

\begin{tabular}{|c|c|}
\hline Executive position & $\begin{array}{c}\text { Total material } \\
\text { compensation (EUR) }\end{array}$ \\
\hline General manager & 47.477 \\
\hline Sales manager & 27.454 \\
\hline Marketing manager & 18.124 \\
\hline Key account manager & 20.340 \\
\hline Financial manager & 19.628 \\
\hline Control manager & 14.246 \\
\hline Human resource manager & 16.136 \\
\hline Transport and logistics manager & 15.494 \\
\hline Facility manager & 13.525 \\
\hline Development manager & 12.988 \\
\hline Average executive compensation & $\mathbf{2 0 . 5 4 1}$ \\
\hline
\end{tabular}

Source: Authors calculation, based onVučković, M. (2012). Plate direktora u privatnim firmama jedan prema otprilike. Biznis\&Finansije. Retrieved from: http://bif.rs/2012/12/plate-direktora-u-privatnim-firmama-jedan-prema-otprilike/.

Another survey on the compensation level and structure, conducted in 2014 by The Republican Bureau of Statistics of the Republic of Serbia, included business organizations with more than 10 employees, and covered 1,189,300 employees (Republican Bureau of Statistics, 2017). According to the conducted research, the highest average compensation was received by „Managers, functionaries and legislators" in the net amount of 1,481,684 RSD (12,250 EUR calculated according to the middle exchange rate of the euro by applying fixed exchange rates of the European Central Bank). The observed compensation included salary, incentives and reimbursement of transport costs (Table 7).

Table 7. Average executive compensation of managers, functionaries and legislators in the Republic of Serbia in 2014

\begin{tabular}{|c|c|c|c|}
\hline $\begin{array}{c}\text { Total material } \\
\text { compensation } \\
\text { (EUR) }\end{array}$ & $\begin{array}{c}\text { Basic salary } \\
\text { (EUR) }\end{array}$ & $\begin{array}{c}\text { Cash incentives } \\
\text { (EUR) }\end{array}$ & $\begin{array}{c}\text { Reimbursement of } \\
\text { transport costs (EUR) }\end{array}$ \\
\hline 12.250 & 11.679 & 389 & 182 \\
\hline
\end{tabular}

Source: Authors calculation, based on Republican Bureau of Statistics. (2017).

Pilot research on the compensation structure for 2014.

Retrieved from: http://publikacije.stat.gov.rs/G2017/Pdf/G20176005.pdf.

The structure of total executive compensation, shown in Table 7, was as follows: 95\% salary (1,412,590 RSD or 11,679 EUR), 3\% incentives (47,092 RSD or 389 EUR), and $2 \%$ reimbursement of transport costs (22,002 RSD or 182 EUR). The compensation of aforementioned group of managers was $79.9 \%$ higher than the average employee compensation in the Republic of Serbia (Republican Bureau of Statistics, 2017). 


\section{Comparison of executive compensation in the Republic of Serbia against EU countries}

Executive compensation largely depend on the business organization size, as well as on the capital structure, ownership structure, possibility for business organization growth, GDP level, managers' age, and many other factors (Ataay, 2018). Large business organizations, operating on the global market and gaining a competitive advantage, earn higher profits than other business organizations. Also, national economies that are important exporters, whose business organizations operate on the global market, gain additional financial capacity and additional financial gain, resulting in increased executive compensations. Therefore it is not difficult to concludethat managers in the UK, Germany and other EU coutries are rewarded with higher compensations than managers in the Republic of Serbia, which is evident from Figure 1.

Figure 1. Comparison of average executive compensation (gross) in 2013

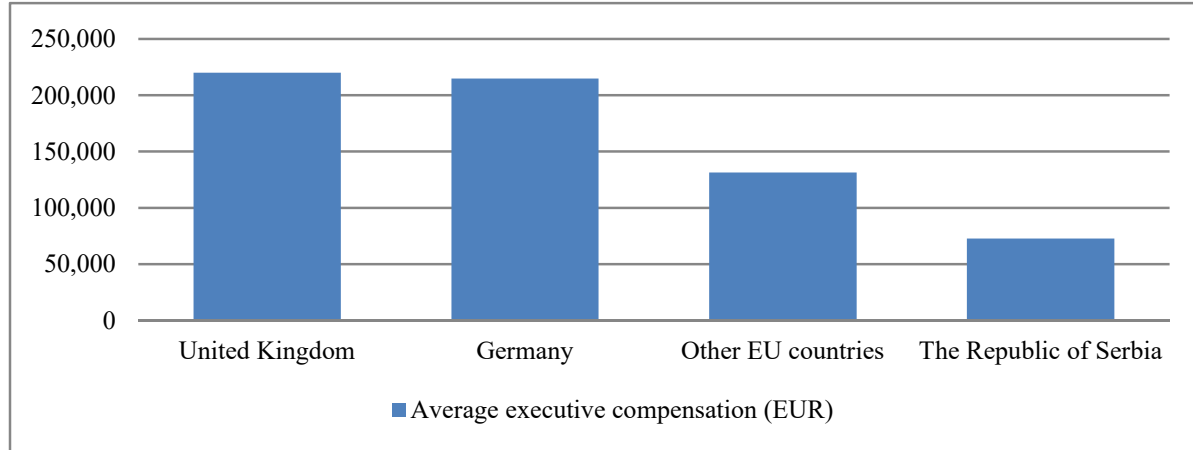

Source: Author, based on Pedersen \& Partners.(2013). Compensation in World's Largest Corporations Increased by $5.5 \%$. Retrieved from

https://www.pedersenandpartners.com/news/2013/10092013-1441/compensationworld $\%$ E2\%80\%99s-largest-corporations-increases-55

From the data shown in Figure 1, there is a clear and large difference in executive compensation levels in observed countries, compared to the Republic of Serbia.However, it was not possible to make a comparison of average level of executive compensation in organizations of different size in Republic of Serbia and selected EU countries. The reason for this is the unavailability of these data for the Republic of Serbia.Data related to average level of executive compensation in organizations of different size are available for other EU countries, so their comparison follows.

Observing the business organizations with over 100,000 employees, the research has shown that the executive salaries in Germany are the largest, compared to all EU countries (1.441.100 EUR). German managers made the largest 
compensations in total thanks to a significant share of cash incentives $(740.000$ EUR), even 106\% compared to base salaries (701.100 EUR). Also, long-term incentives in stock options were paid in a significantly higher amount to managers in Germany (95,000 EUR), compared to managers in the United Kingdom $(31,200$ EUR) and other EU countries (82.200 EUR), as shown in Figure 2.

Figure 2. Comparison of average executive compensation in organizations with over 100.000 employees in 2013

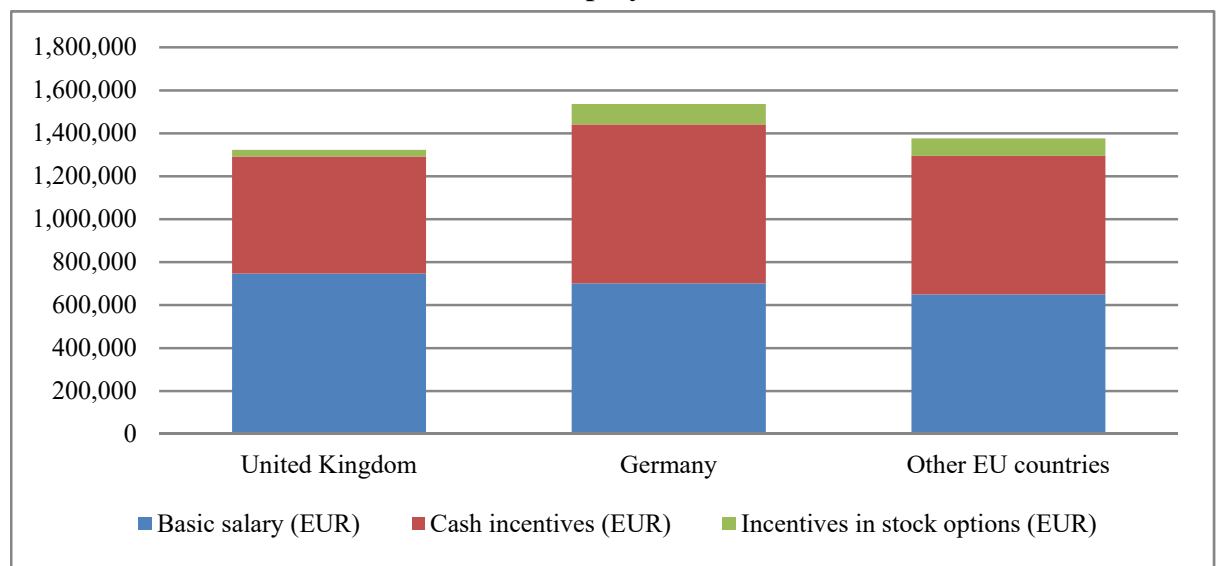

Source: Author, based on Pedersen \& Partners. (2013). Compensation in World's Largest Corporations Increased by $5.5 \%$. Retrieved from

https://www.pedersenandpartners.com/news/2013/10092013-1441/compensationworld $\%$ E2\%80\%99s-largest-corporations-increases-55

The level of executive compansation differs significantly, depending on the size of the organization. Business organization size, closely interconnected with organization growth opportunity, risk and capital structure, is one of the factors that directly or indirectly affect the executive compensation level and structure, as can be seen from the data obtained from the research, which are shown below (Figure 3).

The structure of executive compensation is similar in business organizations with 20-50,000 employees in selected countries. Total executive compensation in Germany is the largest (814.000 EUR), with high share of cash incentives (319.000 EUR) which makes up $39 \%$ of the total compensation. Share of cash incentives is the highest in Germany (39\%) compared to the United Kingdom (33\%) and other EU countries $(28 \%)$, as shown in Figure 3. The research did not provide information on the height of incentives in stock options in business organizations with 20-50,000 employees.

The results of a global executive compensation research, performed by Pedersen \& Partners in 2013 (Pedersen \& Partners, 2013), provided only information on the average level of executive compensation in the Republic of 
Serbia. No deeper analysis was performed, which would show the level and structure of the compensation in organizations with over 100,000 and 20,00050,000 employees.For that reason, it was not possible to make a comparison of average executive compensation in organizations of different size in the Republic of Serbia and selected EU countries.

Figure 3. Comparison of average executive compensation in organizations with 20.000-50.000 employees in 2013

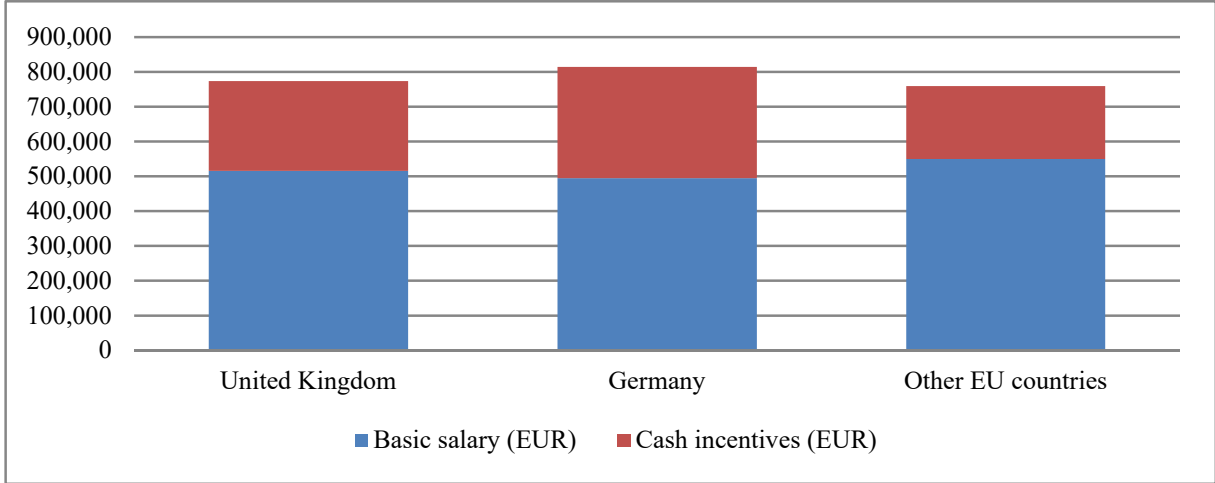

Source: Author, based on Pedersen \& Partners. (2013). Compensation in World's Largest Corporations Increased by $5.5 \%$. Retrieved from https://www.pedersenandpartners.com/news/2013/10092013-1441/compensationworld $\%$ E2\%80\%99s-largest-corporations-increases-55

Evaluation of the research results also confirms the differences in the structure of executive compensation in the Republic of Serbia and observed EU countries. Long term incentives, variable pay based on financial participation occurs more in EU countries then in Republic of Serbia. Figure 4 presents share of organizations that apply different types of variable components of compensation.

In the structure of executive compensation in the Republic of Serbia, long term incentives are very limited. Only a small number of organizations use share plans $(6 \%)$ and stock options (6\%), while a slightly higher number (19\%) applies profit sharing (Figure 4). Germany has the widest use of financial participation within EU countries (15\% shares, $55 \%$ profit sharing, and $11 \%$ stock options); while in the United Kingdom, the use of share plans, profit sharing and stock options is balanced, as well as in other EU countries. Variable pay based on the performances is more used in EU countries then variable pay based on financial participation, which is also true for the Republic of Serbia (Cranet, 2017). It is evident that some components of executive compensation, significantly present in the observed EU countries, are negligible in the Republic of Serbia. 
Figure 4. Proportion of organizations that apply different types of long term incentives (financial participation) 2014-2016

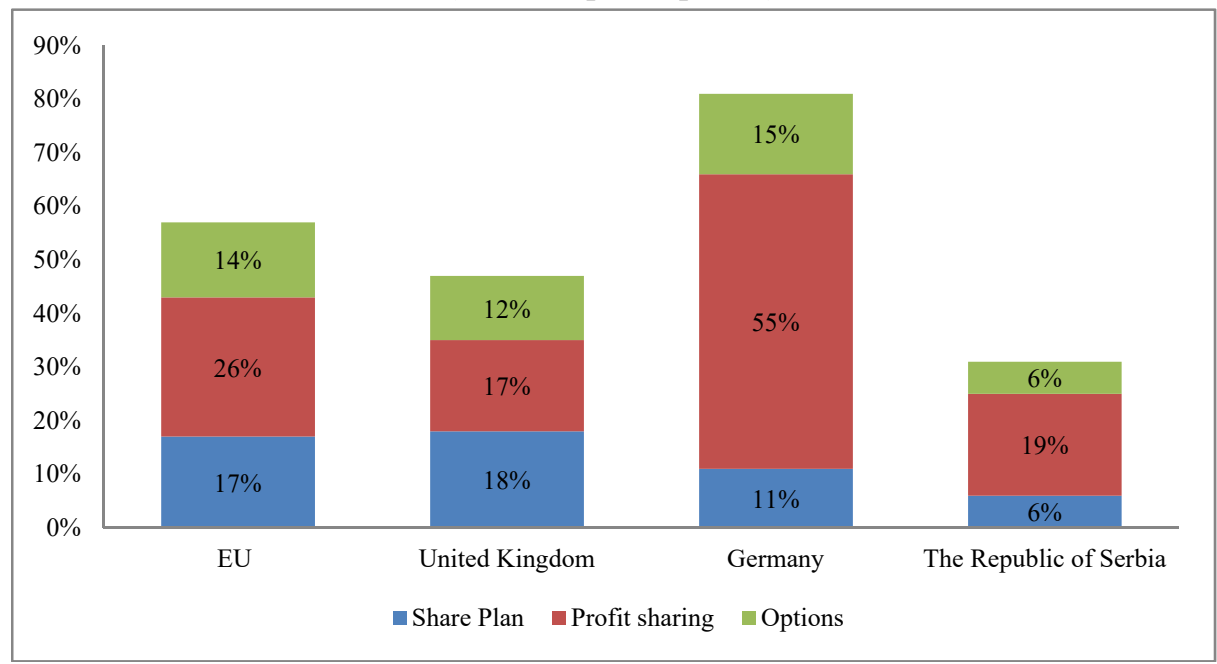

Source: Author, based on Cranet. (2017). Cranet survey on comparative human resource management: International Executive Report. Retrieved from https://www.fdv.unilj.si/docs/default-source/cpocv-doc/cranet-international-report-2017.pdf?sfvrsn=4

Due to high levels of executive compensation in observed EU countries, large incentive payments, and disproportion in relation to compensations of other employees, a certain control measures were introduced. The purpose of control measures was: stronger link between pay and performance; better engagement between organizations and shareholders; shareholders power to hold organizations accountable through binding votes (Petrin, 2015). The 2013 reforms in the United Kingdom introduced the new rules that require at least once every three years a binding shareholder vote on organization's general policy for annual executive compensation. Organizations are required to hold an annual, non-binding advisory vote by shareholders on the executive compensation policy (ERRA, 2013). A better control of executive compensation was also introduced in Germany. There are several benchmarks for executive compensation that need to be obtained by the supervisory board (Marsch-Barner, 2014). Executive compensation needs to be in order with the performances of the manager and should not exceed usual compensation. Executive compensation needs to be orientated upon the sustainable development of the organization, and the supervisory board is supposed to install a cap for unusual developments of executive compensation (Marsch-Barner, 2014). Global economic crisis has caused some changes in the regulation of executive compensations in the French Republic. In 2012, the French government imposed limitations on compensation in state-owned business organizations and increased control over the stock options as long-term incentives (AFP, 2012). Taking into 
account the level of executive compensation, the French Republic introduced a tax rate on highest income of $75 \%$ (AFP, 2012). In the Republic of Serbia, no measures were taken regarding executive compensation control, which was expected considering the level and structure of executive compensations.

\section{Conclusion}

Strategic goals and competitive advantage of business organization can be achieved by engaging managers of appropriate skills. Managers are the most important assets of each organization and it is necessary to achieve their high motivation for accomplishing the business goals. This can be achieved by closely relating executive compensation to desired performances. Business organization should create adequate executive compensation model, and include all the necessary incentives and benefits to attract and retain top-level managers. The executive compensation package, offered by the business organization, must be adequately planned and created according to managers' needs, thereby achieving better productivity of their work. Managers need to be provided with adequate compensation model, which will improve their performances, and motivate them in achieving the desiredstrategic goals. However, before the last global economic crisis, the levels of executive compensation in all countries has been rising dramatically. In recent years, oversized executive compensation, and its disproportion compared to other employees' compensation, has been the object of public interest.

Comparative analysis of executive compensations in the Republic of Serbia and selected EU countriesprovided answers to several research questions. The analysis has covered EU countries (among which the UK and Germany were specially observed) and the Republic of Serbia. The comparative criterion was the level and structure of overall executive compensation.Research has found that executive compensation largely depend on the business organization size, together with the capital and ownership structure and businessgrowth possibility.It has been confirmed that managers in the UK, Germany and other EU countries have higher level of compensation than managers in the Republic of Serbia.German managers are the most rewarded for their business performances in comparison with managers of other EU countries, followed by UK managers.

The research has confirmed that there are large and disproportionate differences in the level of executive compensations, conditioned by the degree of economic development of the observed national economies, as well as many other factors that directly or indirectly affect the level of executive compensation (size of business organization, managers' age, capital structure, ownership structure, etc.). There is a clear large difference in executive compensation levels in observed countries, compared to the Republic of Serbia. However, it was not possible to make a comparison of average level of executive compensation in organizations of 
different size in the Republic of Serbia and EU countries. The reason for this is the unavailability of these data for the Republic of Serbia.

Observing the business organizations with over 100,000 employees, the research has shown that the executive salaries in Germany are the largest, compared to all EU countries. German managers made the largest compensations in total thanks to a significant share of cash incentives, compared to base salary.The level of executive compansation differs significantly, depending on the size of the organization, as it was confirmed by research.The level and structure of executive compensation in business organizations with 20-50,000 employees in selected countries, differs from larger organizations. Total executive compensation in Germany is again the largest in this organizations, with high share of cash incentives in total compensation. It was not possible to make a comparison of average executive compensation in organizations of different size in the Republic of Serbia and selected EU countries. The results of the research provided only information on the average level of executive compensation in the Republic of Serbia. No deeper analysis was performed, which would show the level and structure of the compensation in organizations with over 100,000 and 20,00050,000 employees.

Evaluation of the research results also confirmed the differences in the structure of executive compensation in the Republic of Serbia and EU countries. Some of the executive compensation components, present in EU countries, have negligible participation in the Republic of Serbia. While short-term incentives are present (to a lesser extent) in executive compensation models in the Republic of Serbia, long-term incentives, variable pay based on financial participation, occur more in EU countries then in Republic of Serbia. In the structure of executive compensation in the Republic of Serbia, long term incentives are very limited. Only a small number of organizations use share plans and stock options, while a slightly higher number applies profit sharing. Variable pay based on the performances is more used in EU countries then variable pay based on financial participation, which is also true for the Republic of Serbia. It is evident that some components of executive compensation, significantly present in the observed EU countries, are negligible in the Republic of Serbia.

The global economic crisis has greatly influenced the level of executive compensations across Europe, which has led to government adjustments and limitation of executive compensations. Due to the high levels of executive compensation in EU countries, large incentive payments, and disproportion in relation to compensations of other employees, a certain control measures were introduced. The purpose of control measures was: stronger link between pay and performance; better linkage between organizations and shareholders; shareholders power to hold organizations accountable through binding votes. In the Republic of Serbia, no control measures were taken regarding executive compensation, which was expected considering the lower level and simpler structure of executive compensations. 
Conclusions drawn from this research open the space for further analysis: Do business organizations in the Republic of Serbia use alternative compensation models for motivation of their managers? Is the offer of talented managers on labour market in the Republic of Serbia higher than demand, which enables business organizations to avoid long-term incentives in order to retain quality managers? Could it be that business organizations in the Republic of Serbia do not set long-term goals, so that executive compensation models are consciously based on salary, benefits and short-term incentives? The limitation of this paper is the implementation of executive compensation analysis exclusively in selected EU countries, as well as the use of secondary data sources. The limitation of this paper also is represented in the fact that secondary data sources included different management categories, at different hierarchical levels, engaged in diverse business organizations.

\section{References}

AFP, (2012, Sep 28). France introduces 75 per cent income tax rate for millionaires, TheJournal.ie. Retrieved from https:/www.thejournal.ie/france-tax-millionaires-613581Sep2012/

Amstrong, M., Murlis, H. (2004). Reward Management, London: Kogan Page.

Ataay, A. (2018). Performance sensitivity of executive pay: the role of ownership structure, board leadership structure and board characteristics, Economic Research, 31:1, 11521168.

Beer, M., Katz, N. (2003). Do Incentives Work? The Perception of A Worldwide Sample of Senior Executives, Human Resource Planning 26, no. 3: 30-44.

Buble, M., Bakotić, D. (2013).Kompenzacijski menadžment, Split: Ekonomski fakultet Split.

Cambini, C., De Masi, S., Paci, A., Rondi, L. (2016). The role of the state as controlling shareholder in the telecoms: Incentive versus entrenchment theory, RSCAS 2016/14.Retrieved from http://cadmus.eui.eu/bitstream/handle/1814/39008/RSCAS 2016_14.pdf? sequence $=1 \&$ isAllowed $=\mathrm{y}$

Chingos, P.T. (2004). Responsible Executive Compensation for a New Era of Accountability, New Jersey: J. Wiley \& Sons.

CIPD. (2017). Executive pay: Review of FTSE 100 executive pay packages. Retrieved from https://www.cipd.co.uk/Images/7571-ceo-pay-in-the-ftse100-report-web_tcm1826441.pdf.

Cranet. (2017). Cranet survey on comparative human resource management: International Executive Report. Retrieved from https://www.fdv.uni-lj.si/docs/default-source/cpocvdoc/cranet-international-report-2017.pdf?sfvrsn=4.

Dobre, O.I. (2013). Employee motivation and organizational performance. Review of Applied Socio-Economic Research, 5 (1).

ERRA (2013). Enterprise and Regulatory Reform Act 2013, Retrieved from http://www.legislation.gov.uk/ukpga/2013/24/contents/enacted.

Equilar. (2016, Aug 17). How CEO Pay Differs Around the Globe. Retrieved from http://www.equilar.com/press-releases/53-how-ceo-pay-differs-around-the-globe.html.

Fama, E.F. (1980). Agency Problems and the Theory of the Firm. Journal of Political Economy, 88(2): 288-307.

Frydman, C., Jenter, D. (2010). CEO compensation. Annu. Rev. Financ. Econ., 2(1), 75-102. 
Galetić, L. (2012). Izabrane teme iz kompenzacijskog menadžmenta, Zagreb: Ekonomski fakultet Zagreb.

Goodwin, N., Curry, N., Naylor, C., Ross, S., Duldig, W. (2010). Managing people with longterm conditions. London: The Kings Fund.

Grossman, S.J., Hart, O.D. (1983). An Analysis of the Principal-Agent Problem. Econometrica, 51(1): pp. 7-45.

Grund, C., Walter, T. (2013). Management Compensation and the Economic Crisis: Longitudinal Evidence from the German Chemical Sector, IZA Discussion Paper No. $7435,1-35$.

Haygroup. (2013). Top-executive compensation in Europe in 2012.Retrieved from: https://www.haygroup.com/downloads/uk/Top-executive-compensation-in-Europe2012.pdf.

Heskett, J. (2007). How should pay be linked to performance, Harvard Business School.

Hudson. (2015). Hudson Salary Guides 2015. Retrieved from http://cdn.hudson.com/ Portals/UK/documents/SalarySurveys/Legal-UK-Salary-Tables-2015.pdf.

Jensen, M., Meckling, W. (1976). Theory of the firm: Managerial behavior, agency costs and ownership structure. Journal of Financial Economics 3:5, pp. 305-360.

Koch, R., Stadtmann, G. (2013). Determinants of Supervisory Board Compensation in Germany, International Journal of Economics and Management Engineering (IJEME), Vol. 3 Iss. 2, 56-67.

Kotnik, P., Sakins, M.E., Slavec, A., Gudiraš, D. (2017). Executive compensation in Europe: Realized gains from stock-based pay, ISIGrowth GA,No. 649186.

Marinović Matović, I. (2012). Nagrađivanje menadžera u bankarskom sektoru Srbije, Zadužbina Andrejević, Beograd.

Marinović-Matović, I., Marinović, M. (2011). Sistem motivisanja menadžera u funkciji efikasnog upravljanja, BIZ info anali, 3/2011, 47-56.

Marsch-Barner, R. Schäfer, F.A. (2014). Handbuch Börsennotierte Aktiengesellschaft, 3.Auflage, Gothental.

Mercer. (2013). Compensation and benefit trends in Europe, Retrieved from https://www.mercer.com/content/dam/mercer/attachments/global/Talent/human-capitalagenda/Anthology\%202012/2013-compensation-and-benefit-trends-in-europe-2012mercer.pdf

Murphy, K. (1999). Executive compensation. In: Ashfelder, O. i Card, D. (eds.), Handbook of Labor Economics, Vol. 3B. Amsterdam: North-Holland, pp. 2485-2563.

Oppong, N.Y. (2017). Exploring the importance of human resource activities-strategies alignments: Interactive brainstorming groups approach, Cogent Business \& Management, 4: 1273081.

Pedersen \& Partners. (2013). Compensation in World's Largest Corporations Increased by 5.5\%. Retrieved from https://www.pedersenandpartners.com/news/2013/100920131441/compensation-world $\% \mathrm{E} 2 \% 80 \% 99$ s-largest-corporations-increases- 55 .

Pepper, A., Gore, J., Crossman, A. (2013) Are long-term incentive plans an effective and efficient way of motivating senior executives? Human Resource Management Journal, 23 (1). pp. 36-51.

Petrin, M. (2015). Executive Compensation in the United Kingdom - Past, Present, and Future, Retrieved from http://discovery.ucl.ac.uk/1453284/1/Petrin\%2C\%20M.\%20Executive \%20Compensation\%20.pdf.

Polak, M., Bosna, J., Miletić, J. (2014). Pregled strukture i čimbenika menadžerskih kompenzacija, Privredna kretanja i ekonomska politika, Vol. 23.No. 2. (135), 24-35. 
Republican Bureau of Statistics. (2017). Pilot research on the compensation structure for 2014.Republican Bureau of Statistics, Belgrade. Retrieved from: http://publikacije.stat.gov.rs/G2017/Pdf/G20176005.pdf.

Srivastava, S. K. (2005). Organizational Behaviour and Management.Sarup \& Sons.

Taussig, F. W., Barker, W. S. (1925). American Corporations and Their Executives: A Statistical Inquiry. The Quarterly Journal of Economics, 40(1), pp. 1-51.

Trebilcock, A. (2011). Labour Relations and Human Resources Management: An Overview. Geneva: ILO available online at www.ilo.org/iloenc/part iii Google Scholar.

Vroom, V. (1964). Work and Motivation.Wiley and Sons, New York.

Vučković, M. (2012). Plate direktora u privatnim firmama jedan prema otprilike. Biznis\&Finansije. Retrieved from: http://bif.rs/2012/12/plate-direktora-u-privatnimfirmama-jedan-prema-otprilike/.

\section{KOMPARATIVNA ANALIZA MENADŽERSKIH KOMPENZACIJA U REPUBLICI SRBIJI I ZEMLJAMA EU}

Rezime: Menadžerske kompenzacije imaju snažnu motivacionu ulogu u savremenom korporativnom upravljanju. Adekvatni modeli komenzacionih paketa omogućavaju privlačenje i zadržavanje menadžera visokih sposobnosti, čime se osvaja i održava konkurentska pozicija poslovne organizacije u uslovima globalizacije tržišta. Strategijsko upravljanje menadžerskim kompenzacijama neophodno je uskladiti sa strategijom poslovnog sistema, što zahteva pažljivo planiranje od strane najviših organa upravljačke i vlasničke strukture. Osnovni cilj rada je istraživanje visine najvažnijih komponenti menadžerskih kompenzacija u Republici Srbiji i zemljama EU. U radu je posvećena pažnja značaj u komponenti menadžerskih kompenzacija u zemaljama zapadne $\mathrm{i}$ istočne Europe, pre svega dugoročnih i kratkoročnih stimulacija, kao i plate i beneficija. Istovremeno je izvršena komparativna analiza primenjenih kompenzacionih modela za nagrađivanje menadžera u zemaljama iz posmatranog uzorka. Istraživanjem su utvrđene velike i nesrazmerne razlike $u$ visini menadžerskih kompenzacija, uslovljene stepenom ekonomske razvijenosti posmatranih nacionalnih privreda, kao i brojim drugim faktorima.

Ključne reči: menadžment, menadžerske kompenzacije, korporativno upravljanje, komparativna analiza, Republika Srbija. 


\section{Author's biography}

Ivana Marinović Matović, $\mathrm{PhD}$, began her career in 1997 in the banking sector, in various executive positions. Since 2016, she has been employed in Addiko Bank AD Belgrade, as a Director of Nis Branch within the Retail and SME Sector. Since 2018, she is a certified trainer under the Business Startup Support Programme, organised by the Republic of Serbia, Serbian Chamber of Commerce, Die Deutsche Gesellschaft für Internationale Zusammenarbeit (GIZ) and KfW Development Bank. She has published several papers in scientific and professional journals and a monograph. She has a number of international certifications, among which are: Certificate "Credit Analysis and Monitoring of the Loan portfolio" (Valor Academy, 2015), Honor Code Certificate "ColWri2.1x: How to Write an Essay" (University of California Berkeley, 2015), Certificate "Leasing Academy - Basic Module" (Frankfurt School of Finance \& Management, 2012). 